Article

\title{
Correlating Microbial Community Characteristics with Environmental Factors along a Two-Stage Biological Aerated Filter
}

\author{
Yuchen An ${ }^{1,+}$, Songmin $\mathrm{Li}^{2,+}$, Xiaoling Wang ${ }^{3, *}$, Yuyang Liu ${ }^{1}$ and Ruonan Wang ${ }^{1}$ \\ 1 School of Environmental Science and Engineering, Tianjin University, Tianjin 300072, China; \\ anyuchentju@163.com (Y.A.); 15122267857@163.com (Y.L.); stuwrn@126.com (R.W.) \\ 2 Department of Water Conservancy Engineering, Tianjin Agriculture University, Tianjin 300384, China; \\ lisongmin228@126.com \\ 3 State Key Laboratory of Hydraulic Engineering Simulation and Safety, Tianjin University, \\ Tianjin 300072, China \\ * Correspondence: wangxl@tju.edu.cn; Tel.: +86-022-2789-0911 \\ + These authors contributed equally to this work and should be considered co-first authors.
}

Received: 21 September 2020; Accepted: 17 November 2020; Published: 26 November 2020

check for updates

\begin{abstract}
The purification effect of a biological aerated filter (BAF) mainly comes from the microorganisms in the reactor. Understanding the correlation between microbial community characteristics and environmental factors along the filter has great significance for maintaining good operation and improving the removal efficiency of the filter. A two-stage BAF was employed to treat domestic sewage under organic loads of 1.02 and $1.55 \mathrm{~kg} / \mathrm{m}^{3} \cdot \mathrm{d}$ for 15 days each. $16 \mathrm{~S}$ rDNA high-throughput sequencing technology and redundancy analysis were applied to explore the correlation between microbial community characteristics and environmental variables. The results showed that: (1) the crucial organic-degrading bacteria in the A-stage filter were of the genus Novosphingobium, which had a significant increase in terms of relative abundance at sampling outlet A3 (135 cm of the filling height) after the increase of organic load; (2) the microbial communities at different positions in the B-stage filter were similarly affected by environmental factors, and the main bacteria associated with nitrogen removal in the B-stage filter were Zoogloea and Rhodocyclus; and (3) to improve the pollutant removal performance of this two-stage biological aerated filter, a strategy of adding an internal circulation in the B-stage filter can be adopted.
\end{abstract}

Keywords: microbial community characteristics; environmental factors; two-stage biological aerated filter; redundancy analysis

\section{Introduction}

Biological aerated filters (BAFs) are widely used in sewage treatment systems around the world as part of a sewage treatment process integrating suspended solids retention and biological oxidation [1-4]. Chemical oxygen demand (COD) and nitrogen in the sewage are degraded through metabolism by heterotrophic bacteria, nitrifying bacteria, and denitrifying bacteria that are attached to the filter [5]. However, due to competition from heterotrophic microorganisms, the nitrification space in a traditional BAF is severely compressed [6]. Moreover, the biomass on the front of the filter consumes a large amount of dissolved oxygen (DO), which reduces the DO concentration at the end of the filter and is not conducive to the removal of pollutants such as ammonia nitrogen [7]. Thus, an improved BAF process, such as a two-stage BAF process, can be employed to enhance the efficiency of pollutant removal.

The two-stage BAF process separates the degradation due to different functional bacteria by connecting two filters sequentially and controlling the operating conditions separately, which has the 
advantages of excellent removal efficiency and strong impact resistance $[8,9]$. Research on the two-stage BAF mainly focuses on the influence of operating conditions on pollutant removal rates and the biodegradation process in the filter. A pre-strengthened circulation anaerobic BAF process (SCA-BAF) was reported to effectively remove the nitrogen in municipal wastewater under suitable operating conditions [10]. Wang et al. [11] discovered that an organic degradation-simultaneous nitrification and denitrification (OD-SND) BAF process had the potential for partial nitrification and denitrification. The purification effect of the two-stage BAF mainly comes from the microorganisms in the reactor, and previous studies have investigated the microbial compositions and structures in the filter [12,13]. Nevertheless, the microbial community is strongly correlated with environmental factors. Therefore, understanding the correlation between microbial community characteristics and environmental factors along the filter has great significance for maintaining good operation and improving the removal efficiency of the filter. In recent years, environmental factor correlation analysis has mainly been used to determine the physical and chemical factors associated with the differences between samples, such as in studies of plant root microorganisms [14], marine microorganisms [15], and activated sludge microorganisms [16]. This research mainly studied the correlation between microbial communities and environmental factors in different seasons, different geographical locations, or different treatments. However, there are few studies on the correlation between microorganisms and environmental factors along BAF reactors.

Based on this, the objective of this study was to: (1) understand the relationship between pollutant removal and the microbial community in the two-stage BAF reactor; (2) explore the correlation between the microbial community and environmental factors along the two-stage BAF reactor; and (3) propose an improvement strategy that can increase the pollutant removal rates under the current operating conditions based on the correlation.

\section{Materials and Methods}

\subsection{Description of the Two-Stage BAF System}

A two-stage BAF was employed to treat simulated domestic sewage, and was constructed in a laboratory with an air-conditioning system. The reactor consisted of two filter columns of the same size, which were named the A-stage filter and B-stage filter, respectively (Figure 1). Both filters were cylinders made of polymethyl methacrylate with an inner diameter of $30 \mathrm{~cm}$ and a height $200 \mathrm{~cm}$. A water distribution zone with a height of $10 \mathrm{~cm}$ was set at the bottom of each filter, which was packed with natural zeolite with a diameter of 1-2 cm. A packing zone with a height of $150 \mathrm{~cm}$ was set above and packed with natural zeolite with a diameter of 4-6 $\mathrm{mm}$. The air and sewage entered from the bottom of the filter through the air pump and sewage lift pump. Sampling outlets were set at heights of 25, 85, and $145 \mathrm{~cm}$ for each filter, and were named A1, A2, A3, B1, B2, and B3 according to the direction of sewage flow.

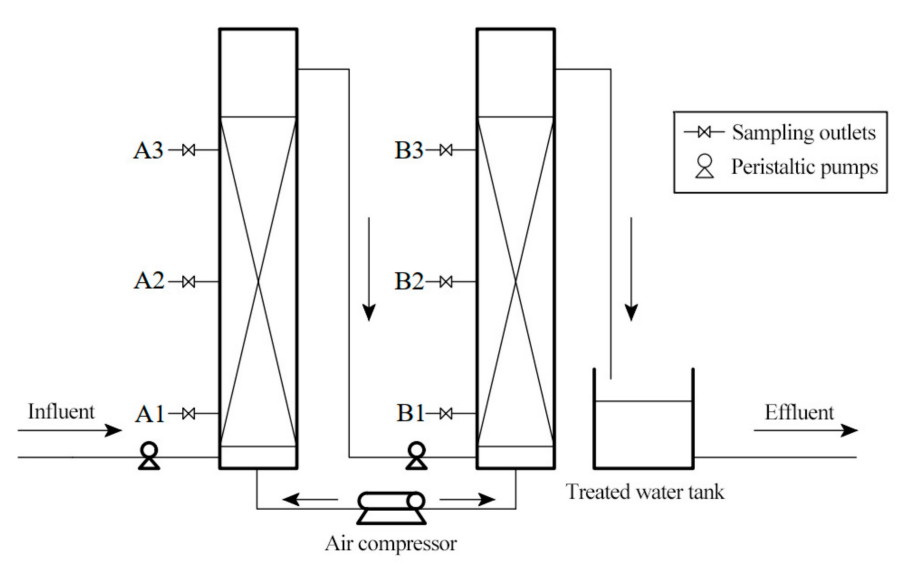

Figure 1. Schematic diagram of the two-stage biological aerated filter (BAF) reactor. 


\subsection{Operation of the Two-Stage BAF}

In the biofilm-culturing period, the two filters were connected end to end. The system was seeded with 2.0 L of activated sludge collected from a local municipal sewage treatment plant. The mixed liquor suspended solids (MLSS) concentration and settlement value (SV) of the activated sludge were $4.5 \mathrm{~g} / \mathrm{L}$ and $28 \%$. The reactor was fed with synthetic wastewater (C:N:P = 100:5:1) at an internal circulation flow of $60 \mathrm{~L} / \mathrm{h}$, and the aeration rate of each filter was $120 \mathrm{~L} / \mathrm{h}$ and $80 \mathrm{~L} / \mathrm{h}$, respectively. One-fifth of the supernatant was drained from the system every day, and an equal volume of synthetic wastewater was replenished. After five days, the two filters were connected in sequence and the reactor began to feed continuously. The hydraulic load was gradually increased from $0.5 \mathrm{~m} / \mathrm{h}$ to $1 \mathrm{~m} / \mathrm{h}$. After 30 days of operation, tawny floccules between the filter interstices were observed, and the ammonia nitrogen removal rates were found to basically stabilize between $60 \%$ and $90 \%$, which indicated the success of the biofilm culturing [17].

In the experimental period, the hydraulic load of the two-stage BAF was set to $1 \mathrm{~m} / \mathrm{h}$, and the air-water ratios of the A and B stage filters were 3:1 and 2:1, respectively [10,18]. The filter was first operated for 15 days under an average organic load of $1.02 \mathrm{~kg} / \mathrm{m}^{3} \cdot \mathrm{d}$, which was recorded as operating period I. By subsequently increasing the influent COD concentration, the average influent organic load reached $1.55 \mathrm{~kg} / \mathrm{m}^{3} \cdot \mathrm{d}$. The filter was operated for another 15 days after the removal rate of ammonia nitrogen was stable, which was recorded as operating period II.

\subsection{Synthetic Wastewater}

The synthetic wastewater was composed of $\mathrm{C}_{6} \mathrm{H}_{12} \mathrm{O}_{6}$ as the main source of $\mathrm{COD}$, and the concentration of COD was changed according to the requirements of the experiments. The other components included $\mathrm{NH}_{4} \mathrm{Cl}(115 \mathrm{mg} / \mathrm{L}), \mathrm{KH}_{2} \mathrm{PO}_{4}(22 \mathrm{mg} / \mathrm{L}), \mathrm{MgSO}_{4}(20 \mathrm{mg} / \mathrm{L}), \mathrm{CaCl}_{2}(15 \mathrm{mg} / \mathrm{L})$, $\mathrm{FeSO}_{4} \cdot 7 \mathrm{H}_{2} \mathrm{O}(10 \mathrm{mg} / \mathrm{L})$, and trace element solution $(1 \mathrm{~mL} / \mathrm{L})$. The trace element solution contained $\mathrm{MnCl}_{2} \cdot 4 \mathrm{H}_{2} \mathrm{O}(0.36 \mathrm{~g} / \mathrm{L}), \mathrm{CuSO}_{4} \cdot 5 \mathrm{H}_{2} \mathrm{O}(0.08 \mathrm{~g} / \mathrm{L}), \mathrm{ZnSO}_{4} \cdot 7 \mathrm{H}_{2} \mathrm{O}(0.30 \mathrm{~g} / \mathrm{L})$, and $\mathrm{CoCl}_{2} \cdot 6 \mathrm{H}_{2} \mathrm{O}(0.38 \mathrm{~g} / \mathrm{L})$. The measured concentration ranges of various pollutants are shown in Table 1 . According to statistical analysis, there was no significant difference in the concentration of other influent pollutants under the two operating conditions, with the exception of COD.

Table 1. Concentration ranges of various pollutants of the synthetic wastewater.

\begin{tabular}{|c|c|c|c|c|c|c|c|}
\hline $\begin{array}{l}\text { Operating } \\
\text { Period }\end{array}$ & $\begin{array}{c}\text { Average } \\
\text { Organic Load } \\
\left(\mathrm{kg} / \mathrm{m}^{3} \cdot \mathrm{d}\right)\end{array}$ & $\begin{array}{c}\text { COD } \\
(\mathrm{mg} / \mathrm{L})\end{array}$ & $\begin{array}{c}\mathrm{NH}_{3}-\mathrm{N} \\
(\mathrm{mg} / \mathrm{L})\end{array}$ & $\begin{array}{c}\text { TN } \\
(\mathrm{mg} / \mathrm{L})\end{array}$ & $\begin{array}{c}\mathrm{NO}_{2}{ }^{-}-\mathrm{N} \\
(\mathrm{mg} / \mathrm{L})\end{array}$ & $\begin{array}{c}\mathrm{NO}_{3}{ }^{-}-\mathrm{N} \\
(\mathrm{mg} / \mathrm{L})\end{array}$ & $\begin{array}{c}\mathrm{NO}_{\mathrm{x}}{ }^{-}-\mathrm{N} \\
(\mathrm{mg} / \mathrm{L})\end{array}$ \\
\hline I & 1.02 & $260(23)$ & 27.59 (3.12) & $32.13(3.76)$ & $0.17(0.08)$ & $3.98(1.23)$ & 4.15 (1.30) \\
\hline II & 1.55 & $392(25)$ & $28.77(2.94)$ & $33.42(3.17)$ & $0.13(0.06)$ & $4.06(0.99)$ & $4.20(1.02)$ \\
\hline
\end{tabular}

\subsection{Sample Collection and Analysis}

The effluent samples were collected from the six outlets every $24 \mathrm{~h}$ during the operating period. Dissolved oxygen (DO) and pH were tested using a DO meter (WTW Oxi3210, German) and $\mathrm{pH}$ meter (WTW pH3210, German). COD (potassium dichromate method), NH3-N (Nessler's reagent spectrophotometry), $\mathrm{NO}_{2}{ }^{-}-\mathrm{N}$ [N-(1-nahpthalene)-diaminoethane method], $\mathrm{NO}_{3}{ }^{-}-\mathrm{N}$ (phenol disulfonic acid spectrophotometry), and TN (alkaline potassium persulphate digestion-UV spectrophotometry) were analyzed according to the monitoring and analysis methods for water and wastewater (Fourth Edition) of China.

After the end of each operating period, zeolite samples at the six sampling outlets A1-A3 and B1-B3 were collected, and MiSeq high-throughput sequencing technology was applied to analyze the diversity of the microbial communities. Microbial DNA was extracted from zeolite samples using the E.Z.N.A. soil DNA Kit (Omega Bio-tek, Norcross, GA, US) according to manufacturer's protocols, and the specific steps were similar to those in previous studies [19]. During the process of PCR 
amplification, the universal bacterial primers 338F (5'-ACTCCTACGGGAGGCAGCA-3') and 806R (5'-GGACTACHVGGGTWTCTAAT-3') were used to amplify the V3 and V4 hypervariable regions of the bacteria $16 \mathrm{~S}$ rRNA. The PCR reactions were conducted using the following program: $3 \mathrm{~min}$ of denaturation at $95{ }^{\circ} \mathrm{C}, 27$ cycles of $30 \mathrm{~s}$ at $95^{\circ} \mathrm{C}, 30 \mathrm{~s}$ for annealing at $55^{\circ} \mathrm{C}, 45 \mathrm{~s}$ for elongation at $72{ }^{\circ} \mathrm{C}$, and a final extension at $72{ }^{\circ} \mathrm{C}$ for $10 \mathrm{~min}$.

Purified amplicons were pooled in equimolar and paired-end sequenced on an Illumina MiSeq platform (Illumina, San Diego, US) according to the standard protocols by Majorbio Bio-Pharm Technology Co. Ltd. (Shanghai, China). Raw fastq files were quality-filtered by Trimmomatic and merged by FLASH, and the reads were truncated at any site receiving an average quality score $<20$ over a $50 \mathrm{bp}$ sliding window. For quality-control purposes, sequences of each sample were separated according to barcodes and primers (allowing 2 nucleotide mismatches), and reads containing ambiguous bases were removed. Operational taxonomic units (OTUs) were clustered with 97\% similarity cutoff using UPARSE with an algorithm that performs chimera filtering and OTU clustering simultaneously. The taxonomy of each 16S rRNA gene sequence was analyzed by an RDP classifier algorithm against the Silva (SSU123) 16S rRNA database using a confidence threshold of 70\%.

\subsection{Data Analysis}

The data of wastewater parameters from the sampling outlets were statistically analyzed using SPSS 22.0 software. One-way analysis of variance (ANOVA) was used to compare the differences in wastewater parameters along the filter under two organic loadings, and differences were considered significant when $\mathrm{p}<0.05$. To explore the correlation between characteristics of microorganisms and environmental factors along the two-stage $\mathrm{BAF}$, redundancy analysis (RDA) was performed using CANOCO 4.5 software. $\mathrm{DO}, \mathrm{pH}, \mathrm{COD}, \mathrm{NH}_{3}-\mathrm{N}, \mathrm{TN}$, and $\mathrm{NO}_{\mathrm{x}}{ }^{-}-\mathrm{N}$, which are closely related to the status of the microbial community, were selected as quantitative environmental factors.

\section{Results and Discussion}

\subsection{Characteristics of Wastewater Parameters and Pollutant Removal Rates along the Filter}

The results of wastewater parameters along the filter showed that all the wastewater parameters, except $\mathrm{NO}_{\mathrm{x}}{ }^{-}-\mathrm{N}$, had a decreasing trend along the direction of wastewater flow (Table 2). Previous studies have demonstrated that the decrease in $\mathrm{pH}$ is due to nitrification in the filter, which requires alkalinity; the decrease in DO is the result of aerobic degradation of the organics and nitrification [20]. The concentration of $\mathrm{NO}_{\mathrm{x}}{ }^{-} \mathrm{N}$ first increased and then decreased along the filter at each stage (Table 2). This is because $\mathrm{NO}_{\mathrm{x}}{ }^{-}-\mathrm{N}$ is both a product of nitrification and an electron acceptor for denitrification. It accumulates due to aerobic nitrification at the front of the filter, and is consumed by anoxic denitrification at the end [21]. The results are similar to those of previous studies [11,22]. It can be seen from the indicated significance that wastewater parameters including $\mathrm{DO}, \mathrm{COD}, \mathrm{NH}_{3}-\mathrm{N}$, and $\mathrm{TN}$ along the filter varied significantly under different organic loads (Table 2). Among these, the difference in DO concentrations at sampling outlet $\mathrm{A} 3$ was the most significant, and the concentrations of $\mathrm{NH}_{3}-\mathrm{N}$ and TN changed obviously at sampling outlets A3 and B1 (Table 2).

The removal rate along the filter was applied to quantify the degradation capacity of the microorganisms. The two-stage BAF had obvious segmented purification characteristics; that is, COD was mainly degraded in the A-stage filter while $\mathrm{NH}_{3}-\mathrm{N}$ and $\mathrm{TN}$ were mainly removed in the B-stage filter (Figure 2). In operating period II, the COD removal rate in section A2-A3 increased from 26.7\% to $36.9 \%$ (Figure 2). The sufficient DO and high concentration of organics resulted in the vigorous metabolism of aerobic heterotrophic bacteria in the A-stage filter [23]. The A-stage filter therefore had a higher removal rate of COD. The B-stage filter had a lower carbon/nitrogen ratio and suitable operating conditions for simultaneous nitrification and denitrification (SND) [18], which led to a high removal rate of $\mathrm{NH}_{3}-\mathrm{N}$ and TN. In operating period II, the increased organic loads seemed to exceed 
the degradation ability of the heterotrophic bacteria in section A1-A2, so more organics were degraded in section $\mathrm{A} 2-\mathrm{A} 3$.

Table 2. Characteristics of wastewater parameter along the filter under two organic loads.

\begin{tabular}{|c|c|c|c|c|c|c|c|}
\hline $\begin{array}{l}\text { Operating } \\
\text { Period }\end{array}$ & $\begin{array}{c}\text { Sampling } \\
\text { Outlet }\end{array}$ & $\begin{array}{c}\mathrm{DO} \\
(\mathrm{mg} / \mathrm{L})\end{array}$ & $\underset{(\mathrm{mg} / \mathrm{L})}{\mathrm{pH}}$ & $\begin{array}{l}\text { COD } \\
(\mathrm{mg} / \mathrm{L})\end{array}$ & $\begin{array}{c}\mathrm{NH}_{3-} \mathrm{N} \\
(\mathrm{mg} / \mathrm{L})\end{array}$ & $\begin{array}{c}\mathrm{TN} \\
(\mathrm{mg} / \mathrm{L})\end{array}$ & $\begin{array}{c}\mathrm{NOx}^{-}-\mathrm{N} \\
(\mathrm{mg} / \mathrm{L})\end{array}$ \\
\hline \multirow{4}{*}{ I } & A1 & $4.33(0.55)$ & $7.86(0.26)$ & $246(22)$ & $26.90(2.72)$ & 31.32 (3.76) & 4.05 (1.47) \\
\hline & A3 & $0.87(0.10)$ & $7.91(0.17)$ & $81(13)$ & $22.32(2.03)$ & $24.86(2.38)$ & $2.53(1.51)$ \\
\hline & B1 & $1.13(0.18)$ & $7.64(0.24)$ & $69(12)$ & $20.89(1.79)$ & $23.29(2.02)$ & $2.27(1.67)$ \\
\hline & B2 & $0.59(0.10)$ & $7.12(0.26)$ & $55(7)$ & $10.12(1.60)$ & $19.20(1.59)$ & 8.59 (1.98) \\
\hline \multirow{5}{*}{ II } & A1 & $4.34(0.51)$ & $7.83(0.19)$ & $369(28) * * *$ & $27.74(2.96)$ & $32.40(3.04)$ & $4.33(1.13)$ \\
\hline & A2 & $1.07(0.23)$ & $7.87(0.24)$ & $225(19)^{* * *}$ & $26.12(2.54) *$ & $30.72(3.11)$ & $4.33(1.60)$ \\
\hline & A3 & $0.60(0.10)^{* * *}$ & $7.95(0.15)$ & $99(11)^{* * *}$ & $25.15(2.14) * * *$ & $28.04(3.11) * *$ & $1.78(0.85)$ \\
\hline & B1 & $1.04(0.16)$ & $7.67(0.16)$ & $86(12)^{* * *}$ & $23.41(1.87)^{* * *}$ & $26.97(2.86)^{* * *}$ & 2.89 (1.28) \\
\hline & B2 & $0.56(0.11)$ & $7.06(0.20)$ & $70(11)^{* * *}$ & $10.98(1.41)$ & $21.55(1.83) * *$ & $9.80(1.60)$ \\
\hline
\end{tabular}
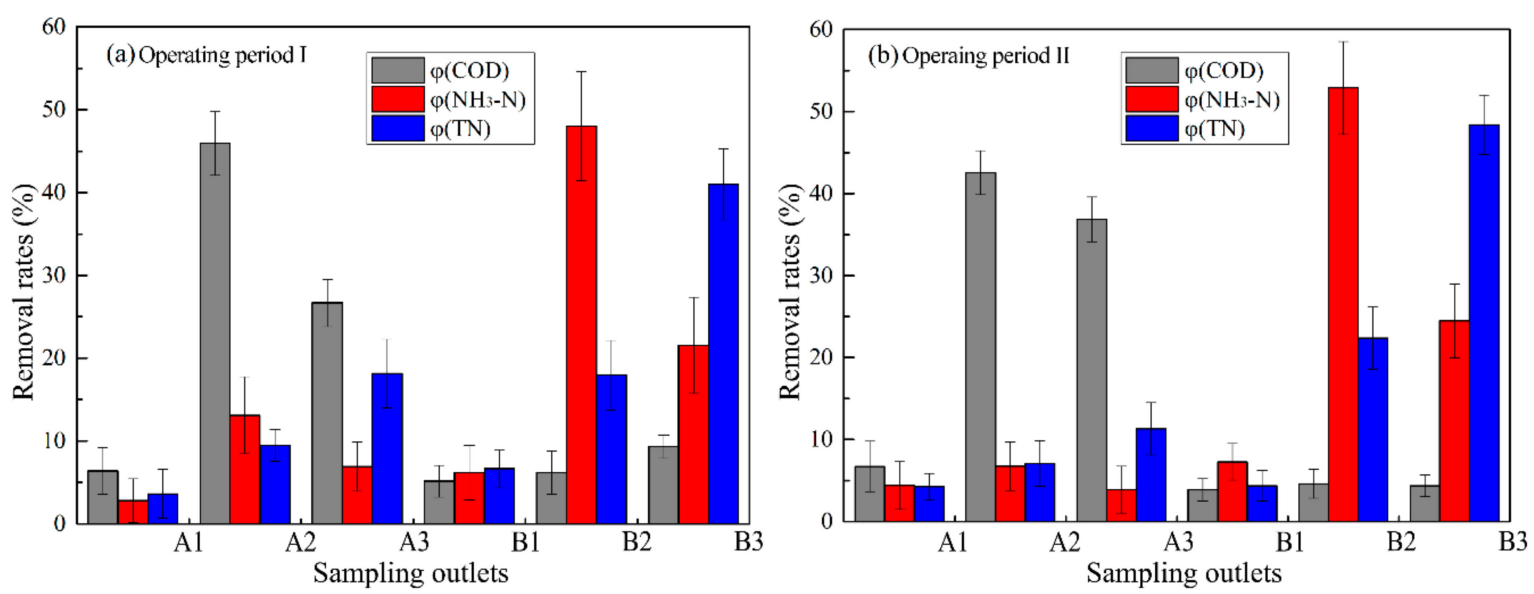

Figure 2. Comparison of pollutant removal rates along the filter under two organic loads. (a) Operating period I; (b) Operating period II.

\subsection{Abundance and Diversity of Microbial Community along the Filter}

A total of 647,760 effective sequences were obtained from the collected microbial samples through 16S rDNA high-throughput sequencing, and 340 OTUs were obtained by clustering, with $97 \%$ similarity. The samples in operating periods I and II were named LA1-LA3, LB1-LB3 and HA1-HA3, HB1-HB3, according to the serial number of the sampling outlet. The coverage rate of each sample was above 0.99 (Table 3), indicating that the amount of sequencing data was suitable. In operating periods I and II, the OTU and Chao index of the A1 sampling outlet were both the smallest (Table 3), which may be related to the fact that this outlet was close to the aeration position, causing loosening of the biofilm structure [24]. The diversity index at each sampling outlet changed after the increase of organic loads. The OTU, ACE, and Chao index, which characterize the richness of the community, decreased at sampling outlets A3 and B1 and increased at the others (Table 3). The Simpson index increased obviously at sampling outlet A3 (Table 3), indicating that a large number of strains gathered there, while the abundance of other species was reduced. The water quality at sampling outlet B1 was similar to that of sampling outlet A3 (Table 2) and, thus, there was a convergence in the changes of the microbial diversity index. 
Table 3. Alpha diversity index along the filter under two organic loads.

\begin{tabular}{cccccc}
\hline Sample & OTU & ACE & Chao & Simpson & Coverage \\
\hline LA1 & 91 & 168 & 162 & 0.18 & 0.999 \\
LA2 & 221 & 259 & 295 & 0.41 & 0.998 \\
LA3 & 229 & 270 & 271 & 0.08 & 0.999 \\
LB1 & 236 & 266 & 260 & 0.09 & 0.999 \\
LB2 & 160 & 192 & 184 & 0.19 & 0.999 \\
LB3 & 191 & 204 & 209 & 0.12 & 0.999 \\
\hline HA1 & 116 & 234 & 162 & 0.16 & 0.999 \\
HA2 & 229 & 266 & 263 & 0.40 & 0.998 \\
HA3 & 210 & 258 & 251 & 0.34 & 0.998 \\
HB1 & 218 & 252 & 259 & 0.07 & 0.999 \\
HB2 & 169 & 258 & 214 & 0.14 & 0.999 \\
HB3 & 191 & 219 & 216 & 0.13 & 0.999 \\
\hline
\end{tabular}

The top 15 of the phyla and genera with the highest relative abundance were displayed in the bar graph, and the rest were classified as "others". According to Figure 3a, the composition of the microbial community of each sample was similar at the phylum level, but the relative abundance was quite different. The dominant phyla of the microbial community were Proteobacteria, Bacteroidetes, Firmicutes, Saccharibacteria, and Acidobacteria (Figure 3a). The microbial composition was similar to that of the activated sludge from municipal sewage treatment plants [25]. Bacteria of the phylum Proteobacteria, which are associated with various activities such as organic degradation, nitrification, and denitrification, were the most abundant, accounting for $52.1 \%-85.3 \%$ of the sample $[26,27]$. Most bacteria in the Bacteroidetes phylum have the ability of denitrification and are the dominant bacteria species in SND reactors [28,29], accounting for the generally higher abundance of Bacteroides in the B-stage filter compared to the A-stage. In addition, a higher abundance of Firmicutes bacteria was observed in the samples of LA1 and HA1, which may be related to the degradation of the high concentration of organics at the wastewater inlet by Clostridium bacteria within the phylum Firmicutes [30] (Figure 3b).

(a)

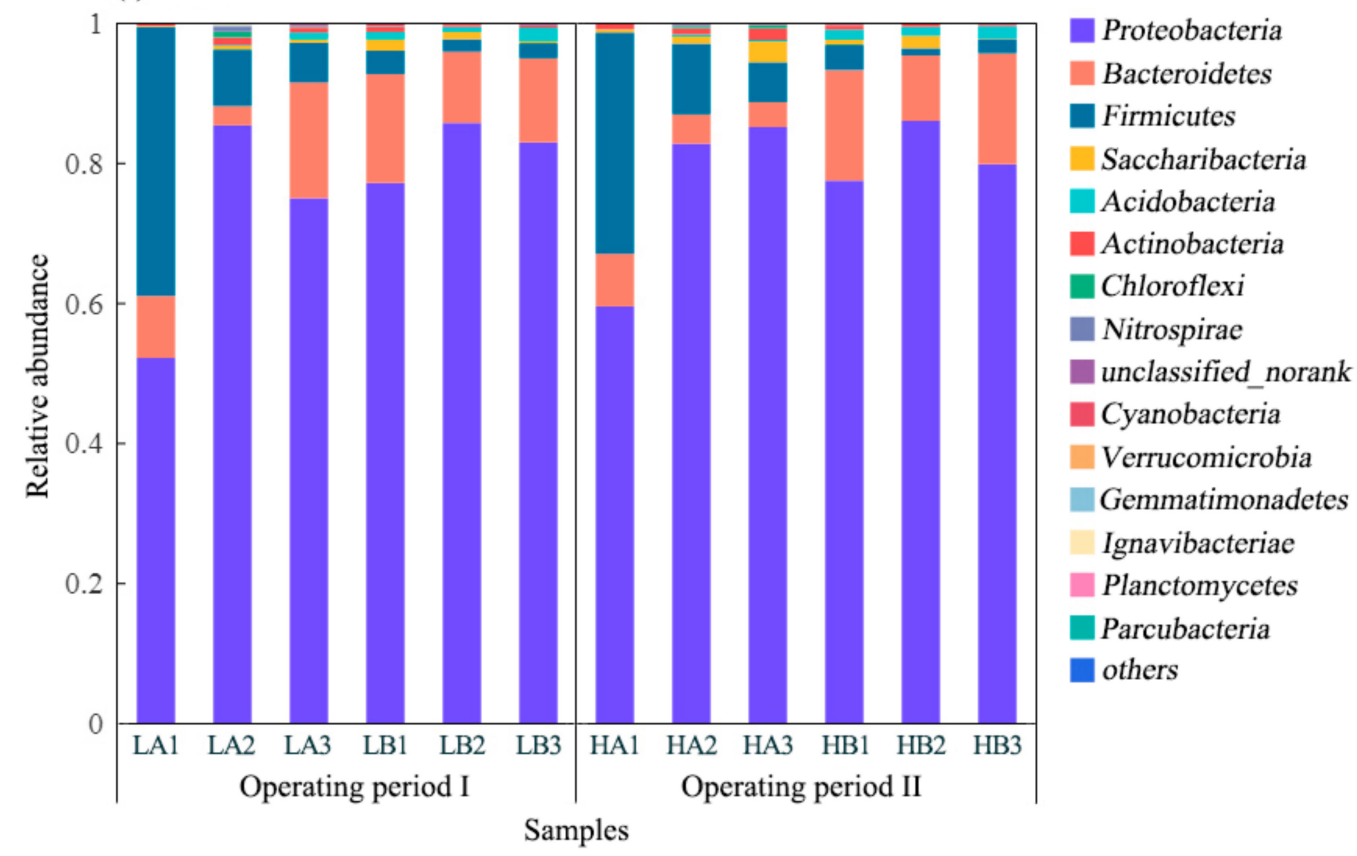

Figure 3. Cont. 
(b)

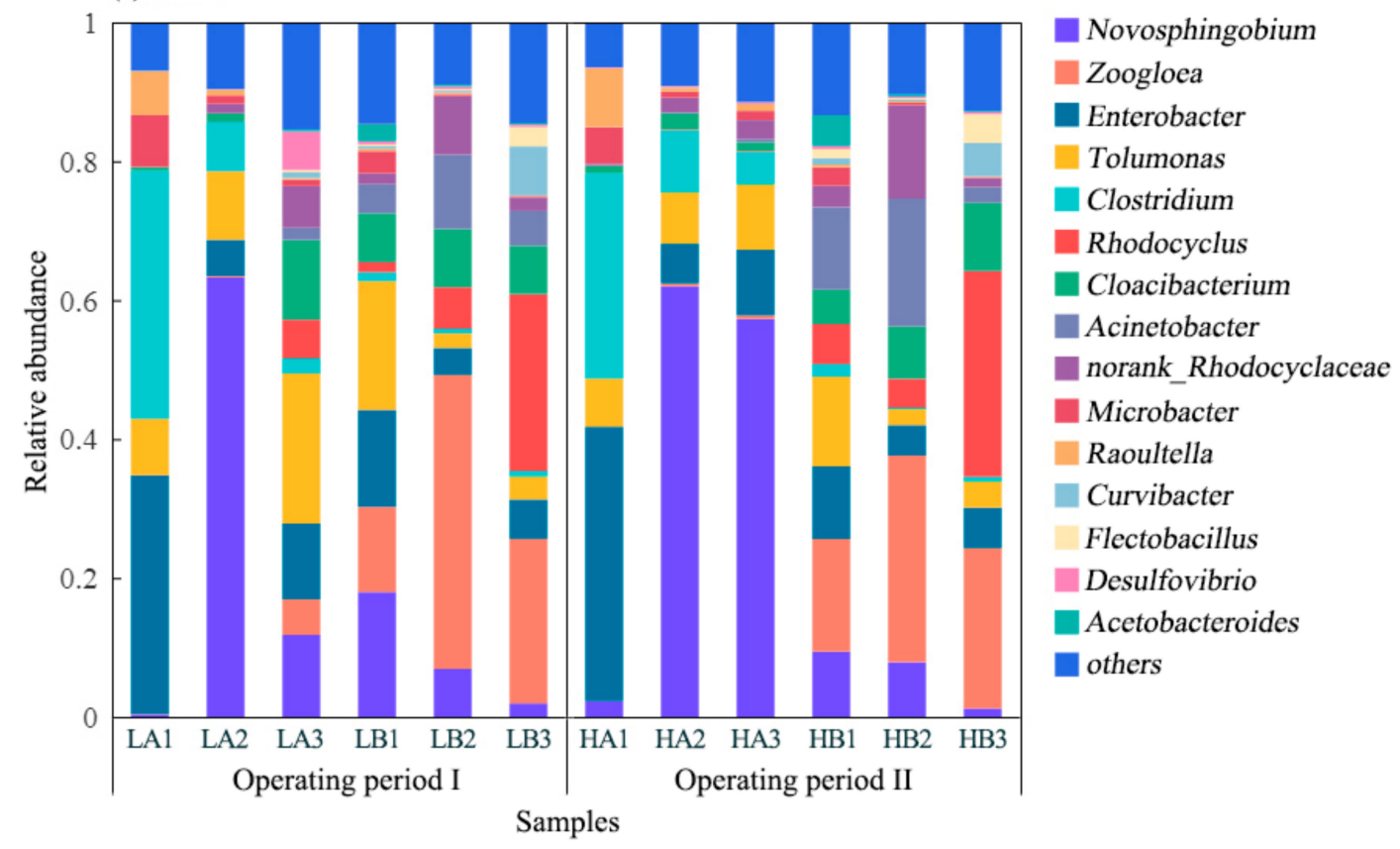

Figure 3. The relative abundance of bacteria along the filter under two organic loads. (a) At phylum level; (b) At genus level.

Each sample from different spatial locations and under different operating conditions had obvious differences in the microbial community structures at the genus level (Figure 3b). The most abundant genus, Novosphingobium, belongs to the phylum Proteobacteria and was mainly distributed at sampling outlet A2 (Figure $3 b$ ). Following the increase in organic loads, a significant increase in the abundance of Novosphingobium was observed at sampling outlet A3 (Figure 3b). It has been reported that Novosphingobium has the ability to degrade a variety of organic pollutants [31,32]. The relative abundance of Novosphingobium at sampling outlet A3 indicated that Novosphingobium had the potential to degrade $\mathrm{C}_{6} \mathrm{H}_{12} \mathrm{O}_{6}$, and that the increase in organic loads made the distribution area of Novosphingobium longer in the filter. Similar results have been previously reported, and the phenomenon suggested plasticity in the microbial population, which could ensure a good performance of the reactor under different operating conditions [33]. Furthermore, Zoogloea and Rhodocyclus have always been considered to perform well in denitrification [34,35], which mainly existed in the B-stage filter of the two-stage BAF (Figure 3b). Enterobacter and Clostridium mainly existed at sampling outlet A1 (Figure $3 b$ ), which was considered to be related to the degradation of organics in the filter $[30,36]$.

\subsection{Correlation between Microbial Communities and Environmental Factors}

Redundancy analysis (RDA) was employed to evaluate the correlation between microbial communities (top $90 \%$ of the genera in relative abundance) and environmental factors. Six variables were selected, namely DO, $\mathrm{pH}, \mathrm{COD}, \mathrm{NH}_{3}-\mathrm{N}, \mathrm{TN}$, and $\mathrm{NO}_{\mathrm{x}}{ }^{-}-\mathrm{N}$. The genera Enterobacter and Clostridium were anaerobic microorganisms, but they distributed close to positions of high DO concentrations indicated by the arrow (Figure 4). A possible reason may be that these bacteria grew at the bottom of the biofilms formed, where DO concentration diminished due to its consumption by aerobic microorganisms at the top layers of the biofilm community that thrived due to the high COD concentration. Similar results were also found in Zhang's research [37]. The genus Novosphingobium was not close to any arrow (Figure 4), implying that the combined influence of multiple variables led to the significantly changed abundances at sampling outlet A3 [16]. In the B-stage filter, the genera Zoogloea and Rhodocyclus were positively correlated with the $\mathrm{NO}_{\mathrm{x}}{ }^{-}-\mathrm{N}$ concentration and negatively with the $\mathrm{pH}, \mathrm{NH}_{3}-\mathrm{N}$, and $\mathrm{TN}$ concentrations (Figure 4). Previous studies have shown that these bacteria 
have the effect of denitrification [34,35], indicating that the denitrification rate in the B-stage filter mainly depended on the concentration of the reaction substrate. According to the angle of the arrows (Figure 4), the removal of $\mathrm{NH}_{3}-\mathrm{N}$ and $\mathrm{TN}$ was consistent in the two-stage BAF, and was positively correlated with the decrease in $\mathrm{pH}$, which was caused by the consumption of alkalinity during the nitrification process. Moreover, the distance from the sample points to the environmental factors of the A-stage filter (Figure 4) indicates that the DO and COD concentrations were the main driving forces leading to differences in the microbial community structure of the A-stage filter. However, the sample points of the B-stage filter are relatively close, and are located between the extension lines of the environmental factor arrows (Figure 4), which indicates that the microbial communities at different positions in the B-stage filter were similarly affected by environmental factors.

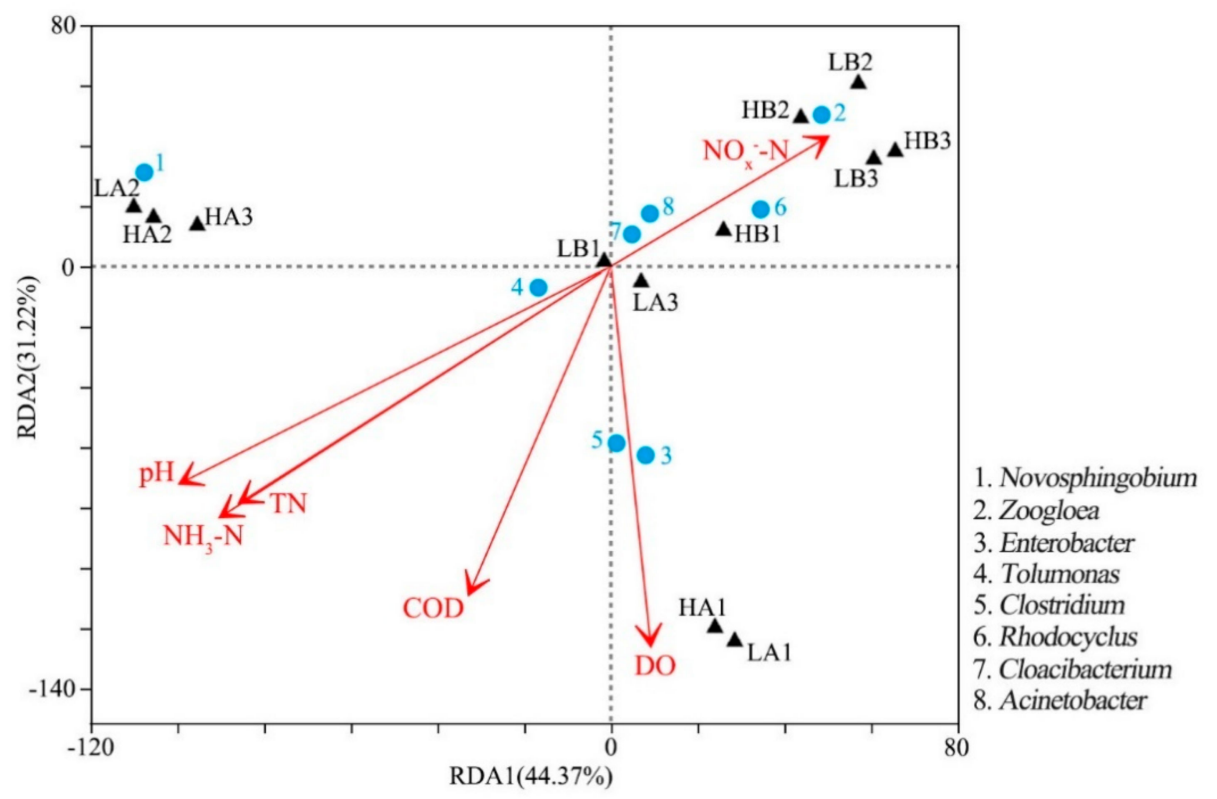

Figure 4. Redundancy analysis (RDA) map based on the sequencing data and environmental variables. The black triangle represents the sample, the blue dot represents the microbial at the genus level, and the arrow represents environmental factors.

Based on the correlation between microbial community characteristics and environmental factors along the two-stage biological aerated filter, we can propose a series of strategies for improving the removal rates of pollutants which are suitable for this filter. As the genus Novosphingobium that contributed the most to the removal of organics in the A-stage filter was affected by a combination of various environmental factors (Figure 4), the removal rate of organics cannot be increased by enhancing the aeration or adding alkalinity alone. The A-stage filter can adjust the distribution area of the genus Novosphingobium to adapt to the change of organic loads, which indicates that increasing the filler height of the A-stage filter can improve the capacity of COD degradation of the two-stage BAF under higher organic loads. However, increasing filler height has limited improvement effect on pollutant removal rates under lower pollution loads. The removal rates of pollutants along the BAF decreases with the increase of filler height in Yan's and Li's research [17,38]. According to the characteristics of $\mathrm{NO}_{\mathrm{x}}{ }^{-}-\mathrm{N}$ distribution in the B-stage filter (Table 2) and the fact that the denitrification rate in the B-stage filter mainly depended on the concentration of the reaction substrate, an internal circulation in the B-stage filter can be adopted to improve the removal efficiency of nitrogen. Similar strategies have been adopted in recent studies [39,40], and the results showed that the internal circulation enhanced the wastewater treatment capacity of the filter system by improving mass transfer efficiency between the sewage and biofilm. In summary, adding an internal circulation to the B-stage filter can be adopted to improve the pollutant removal performance of this two-stage biological aerated filter. 


\section{Conclusions}

Understanding the correlation between microbial community characteristics and environmental factors along the filter has great significance for maintaining good operation and improving the removal efficiency of the filter. The noteworthy results from this study are as follows:

(1) In the A-stage filter, the crucial organic-degrading bacteria were of the genus Novosphingobium, which had a significant increase in terms of relative abundance at sampling outlet A3 after the enhancement of organic load. The DO and COD concentrations were the main driving forces leading to differences in the microbial community structure of the A-stage filter.

(2) In the B-stage filter, the microbial communities at different positions were similarly affected by environmental factors. The main bacteria associated with nitrogen removal in the B-stage filter were Zoogloea and Rhodocyclus.

(3) To improve the pollutant removal performance of this two-stage biological aerated filter, a strategy of adding an internal circulation in the B-stage filter can be adopted.

Author Contributions: Y.A. and S.L. conceived, designed, and wrote the paper; X.W. provided the help of program implementation and funds; Y.L. and R.W. revised the manuscript. All authors have read and agreed to the published version of the manuscript.

Funding: This research was supported by the Water Pollution Control and Management of National Science and Technology Major Projects in China (2017ZX07204-003).

Conflicts of Interest: The authors declare no conflict of interest.

\section{References}

1. Zhou, Y.; Zhou, Y.; Sun, X.; Fu, L. The recent development of advanced wastewater treatment by ozone and biological aerated filter. Environ. Sci. Pollut. Res. 2018, 25, 8315-8329. [CrossRef]

2. Abou-Elela, S.I.; Abo-El-Enein, S.A.; Hellal, M.S. Utilization of autoclaved aerated concrete solid waste as a bio-carrier in immobilized bioreactor for municipal wastewater treatment. Desalin. Water Treat. 2019, 168, 108-116. [CrossRef]

3. Vieira, A.; Marques, R.; Galinha, C.; Povoa, P.; Carvalho, G.; Oehmen, A. Nitrous oxide emissions from a full-scale biological aerated filter (BAF) subject to seawater infiltration. Environ. Sci. Pollut. Res. 2019, 26, 20939-20948. [CrossRef] [PubMed]

4. Al-Ghouti, M.A.; Al-Kaabi, M.A.; Ashfaq, M.Y.; Da'Na, D.A. Produced water characteristics, treatment and reuse: A review. J. Water Process. Eng. 2019, 28, 222-239. [CrossRef]

5. Fdz-Polanco, F.; Mendez, E.; Urueña, M.; Villaverde, S.; García, P. Spatial distribution of heterotrophs and nitrifiers in a submerged biofilter for nitrification. Water Res. 2000, 34, 4081-4089. [CrossRef]

6. Madoni, P.; Davoli, D.; Fontani, N.; Cucchi, A.; Rossi, F. Spatial Distribution of Microorganisms and Measurements of Oxygen Uptake Rate and Ammonia Uptake Rate Activity in a Drinking Water Biofilter. Environ. Technol. 2001, 22, 455-462. [CrossRef]

7. Benáková, A.; Johanidesová, I.; Kelbich, P.; Pospíšil, V.; Wanner, J. The increase of process stability in removing ammonia nitrogen from wastewater. Water Sci. Technol. 2018, 77, 2213-2219. [CrossRef]

8. Sun, J.; Li, Y.; Zhang, Y. Study on Treatment Process Improvement of Herbal Drug Wastewater. Asian J. Chem. 2013, 25, 951-953. [CrossRef]

9. Pan, L.T.; Han, Y. A novel anoxic-aerobic biofilter process using new composite packing material for the treatment of rural domestic wastewater. Water Sci. Technol. 2016, 73, 2486-2492. [CrossRef]

10. Yang, B.; Wang, J.; Wang, J.-F.; Xu, H.; Song, X.; Wang, Y.; Li, F.; Liu, Y.; Bai, J. Correlating microbial community structure with operational conditions in biological aerated filter reactor for efficient nitrogen removal of municipal wastewater. Bioresour. Technol. 2018, 250, 374-381. [CrossRef]

11. Wang, C.; Wang, B.; Wang, L. The simultaneous nitrification and denitrification characteristics of two-stage biological aerated filter. China Environ. Sci. 2005, 25, 70-74, (In Chinese Journal).

12. White, C.P.; DeBry, R.W.; Lytle, D.A. Microbial Survey of a Full-Scale, Biologically Active Filter for Treatment of Drinking Water. Appl. Environ. Microbiol. 2012, 78, 6390-6394. [CrossRef] [PubMed] 
13. Feng, X.; Wang, X.; Chen, Z.; Chen, J. Nitrogen removal from iron oxide red wastewater via partial nitritation-Anammox based on two-stage zeolite biological aerated filter. Bioresour. Technol. 2019, 279, 17-24. [CrossRef] [PubMed]

14. Dean, S.L.; Farrer, E.C.; Porras-Alfaro, A.; Suding, K.N.; Sinsabaugh, R.L. Assembly of root-associated bacteria communities: Interactions between abiotic and biotic factors. Environ. Microbiol. Rep. 2014, 7, 102-110. [CrossRef] [PubMed]

15. Tisthammer, K.H.; Cobian, G.M.; Amend, A.S. Global biogeography of marine fungi is shaped by the environment. Fungal Ecol. 2016, 19, 39-46. [CrossRef]

16. Ju, F.; Guo, F.; Ye, L.; Xia, Y.; Zhang, T. Metagenomic analysis on seasonal microbial variations of activated sludge from a full-scale wastewater treatment plant over 4 years. Environ. Microbiol. Rep. 2014, 6, 80-89. [CrossRef]

17. Yan, G.; Xu, X.; Yao, L.; Lu, L.; Zhao, T.; Zhang, W. Process of inorganic nitrogen transformation and design of kinetics model in the biological aerated filter reactor. Bioresour. Technol. 2011, 102, 4628-4632. [CrossRef]

18. Ma, W.; Han, Y.; Ma, W.; Han, H.; Zhu, H.; Xu, C.; Li, K.; Wang, D. Enhanced nitrogen removal from coal gasification wastewater by simultaneous nitrification and denitrification (SND) in an oxygen-limited aeration sequencing batch biofilm reactor. Bioresour. Technol. 2017, 244, 84-91. [CrossRef]

19. Li, L.; Sun, Y.; Yuan, Z.; Kong, X.; Wao, Y.; Yang, L.; Zhang, Y.; Li, D. Effect of microalgae supplementation on the silage quality and anaerobic digestion performance of Manyflower silvergrass. Bioresour. Technol. 2015, 189, 334-340. [CrossRef]

20. Hocaoglu, S.M.; Insel, G.; Cokgor, E.U.; Orhon, D. Effect of low dissolved oxygen on simultaneous nitrification and denitrification in a membrane bioreactor treating black water. Bioresour. Technol. 2011, 102, 4333-4340. [CrossRef]

21. Lima, P.S.; Dezotti, M.; Bassin, J.P. Interpreting the effect of increasing COD loading rates on the performance of a pre-anoxic MBBR system: Implications on the attached and suspended biomass dynamics and nitrification-denitrification activity. Bioprocess. Biosyst. Eng. 2016, 39, 945-957. [CrossRef] [PubMed]

22. Ren, J.; Cheng, W.; Wan, T.; Wang, M.; Zhang, C. Effect of Aeration Rates and Filter Media Heights on the Performance of Pollutant Removal in an Up-Flow Biological Aerated Filter. Water 2018, 10, 1244. [CrossRef]

23. Contreras, C.R.; López, D.; Leiva, A.M.; Domínguez, C.; Bayona, J.M.; Vidal, G. Removal of Organic Micropollutants in Wastewater Treated by Activated Sludge and Constructed Wetlands: A Comparative Study. Water 2019, 11, 2515. [CrossRef]

24. Celmer, D.; Oleszkiewicz, J.; Cicek, N. Impact of shear force on the biofilm structure and performance of a membrane biofilm reactor for tertiary hydrogen-driven denitrification of municipal wastewater. Water Res. 2008, 42, 3057-3065. [CrossRef] [PubMed]

25. Gao, P.; Xu, W.; Sontag, P.; Li, X.; Xue, G.; Liu, T.; Sun, W. Correlating microbial community compositions with environmental factors in activated sludge from four full-scale municipal wastewater treatment plants in Shanghai, China. Appl. Microbiol. Biotechnol. 2016, 100, 4663-4673. [CrossRef] [PubMed]

26. Freixa, A.; Ejarque, E.; Crognale, S.; Amalfitano, S.; Fazi, S.; Butturini, A.; Romaní, A.M. Sediment microbial communities rely on different dissolved organic matter sources along a Mediterranean river continuum. Limnol. Oceanogr. 2016, 61, 1389-1405. [CrossRef]

27. Callejas, C.; Fernández, A.; Passeggi, M.; Wenzel, J.; Bovio, P.; Borzacconi, L.; Etchebehere, C. Microbiota adaptation after an alkaline $\mathrm{pH}$ perturbation in a full-scale UASB anaerobic reactor treating dairy wastewater. Bioprocess. Biosyst. Eng. 2019, 42, 2035-2046. [CrossRef]

28. Pelaez, A.I.; Fernández-Nava, Y.; Soons, J.; Martinez-Toledo, M.V.; Maranon, E.; Sanchez, J. Population analysis in high-nitrate wastewater treatment in sequencing batch reactors. Environ. Eng. Manag. J. 2016, 15, 93-103. [CrossRef]

29. Sul, W.-J.; Kim, I.-S.; Ekpeghere, K.I.; Song, B.; Kim, B.-S.; Kim, H.-G.; Kim, J.-T.; Koh, S.-C. Metagenomic insight of nitrogen metabolism in a tannery wastewater treatment plant bioaugmented with the microbial consortium BM-S-1. J. Environ. Sci. Heal. Part. A 2016, 51, 1164-1172. [CrossRef]

30. Das, S.; Jeong, S.T.; Das, S.; Kim, P.J. Composted Cattle Manure Increases Microbial Activity and Soil Fertility More Than Composted Swine Manure in a Submerged Rice Paddy. Front. Microbiol. 2017, 8, 1702. [CrossRef]

31. Chettri, B.; Singh, A.K. Kinetics of hydrocarbon degradation by a newly isolated heavy metal tolerant bacterium Novosphingobium panipatense P5:ABC. Bioresour. Technol. 2019, 294, 122190. [CrossRef] [PubMed] 
32. Ibero, J.; Galán, B.; Diaz, E.; García, J.L. Testosterone Degradative Pathway of Novosphingobium tardaugens. Genes 2019, 10, 871. [CrossRef] [PubMed]

33. Gulhane, M.; Pandit, P.; Khardenavis, A.; Singh, D.; Purohit, H. Study of microbial community plasticity for anaerobic digestion of vegetable waste in Anaerobic Baffled Reactor. Renew. Energy 2017, 101, 59-66. [CrossRef]

34. Szabó, E.; Liébana, R.; Hermansson, M.; Modin, O.; Persson, F.; Wilén, B.-M. Microbial Population Dynamics and Ecosystem Functions of Anoxic/Aerobic Granular Sludge in Sequencing Batch Reactors Operated at Different Organic Loading Rates. Front. Microbiol. 2017, 8, 770. [CrossRef]

35. Kim, E.; Shin, S.G.; Jannat, A.H.; Tongco, J.V.; Hwang, S. Use of food waste-recycling wastewater as an alternative carbon source for denitrification process: A full-scale study. Bioresour. Technol. 2017, 245, 1016-1021. [CrossRef]

36. Poddar, K.; Sarkar, D.; Sarkar, A. Construction of potential bacterial consortia for efficient hydrocarbon degradation. Int. Biodeterior. Biodegrad. 2019, 144. [CrossRef]

37. Zhang, Q.; Wang, C.; Jiang, L.; Qi, J.; Wang, J.; He, X. Impact of dissolved oxygen on the microbial community structure of an intermittent biological aerated filter (IBAF) and the removal efficiency of gasification wastewater. Bioresour. Technol. 2018, 255, 198-204. [CrossRef]

38. Li, J.; Wang, X.; Han, J.; Qian, Y. Removal regularity of textile wastewater pollutants in biological aerated filter. Chin. J. Environ. Eng. 2012, 6, 1167-1170, (In Chinese Journal).

39. Zhang, X.; Li, Q.; Wang, J.; Wang, X.; Lin, Y. Research progress process improvement of biological aerated filter: A review. Chem. Ind. Eng. Prog. 2015, 34, 2023-2030, (In Chinese Journal).

40. Wang, C.; Peng, Z.; Feng, K.; Chen, Z.; Liu, H. A study on the treatment efficiency of internal circulation biological aerated filters for refinery wastewater and the transformation of main organic pollutants. Environ. Sci. Pollut. Res. 2020, 27, 22902-22912. [CrossRef]

Publisher's Note: MDPI stays neutral with regard to jurisdictional claims in published maps and institutional affiliations.

(C) 2020 by the authors. Licensee MDPI, Basel, Switzerland. This article is an open access article distributed under the terms and conditions of the Creative Commons Attribution (CC BY) license (http://creativecommons.org/licenses/by/4.0/). 